\title{
Heavy Metal Pollution and Human Health Risk Assessment of Farmlands around Enyigba Lead-Zinc Mining Site, Ebonyi State, Nigeria
}

\author{
Nwogo Ajuka Obasi ${ }^{1}$, Stella Eberechukwu Obasi ${ }^{2}$, Emmanuel Nweze $^{3}$, Solomon Okechukwu Amadi ${ }^{4}$, \\ Chinyere Aloke ${ }^{1}$, and Getrude Obinaju Aloh ${ }^{5}$ \\ ${ }^{1}$ Environmental Biochemistry, Health and Toxicology Research Unit, Department of Medical Biochemistry, Alex \\ Ekwueme Federal University \\ Ndufu-Alike, Ebonyi State, Nigeria \\ ajuka.obasi@funai.edu.ng; alokec2002@yahoo.com
}

${ }^{2}$ Plant Ecology Research Unit, Department of Science Laboratory Technology, Akanu Ibiam Federal Polytechnic Unwana

Ebonyi State, Nigeria

stellaeobasi@gmail.com

${ }^{3}$ Department of Maths/Comp. Sc/Stat/Info., Alex Ekwueme Federal University Ndufu-Alike

Ebonyi State, Nigeria

nwaezeema@yahoo.com

${ }^{4}$ Department of Physics/Geology/Geophysics, Alex Ekwueme Federal University Ndufu-Alike

Ebonyi State, Nigeria

solomonokeamadi@gmail.com

${ }^{5}$ Department of Geography and Meteorology, Enugu State University of Science and Technology

Enugu State, Nigeria.

hewiedconsultnl@gmail.com

\begin{abstract}
This study evaluated the chemical forms of heavy metals contamination in soil, its level in vegetables and the health risks for resident farmers within vicinity of $\mathrm{Pb}-\mathrm{Zn}$ mining site in Enyigba Community, Abakaliki, Ebonyi State, Nigeria. Soil and vegetable samples were obtained from mapped farmlands within the vicinity of the mining sites and farmlands in non-mining site as control and analyzed using standard analytical protocols. The results showed high $\%$ association of $\mathrm{Cd}, \mathrm{Pb}, \mathrm{Fe}$ and $\mathrm{Zn}$ in non-residual fraction and high \% association of $\mathrm{Cu}, \mathrm{Cr}$ and $\mathrm{Ni}$ in residual fraction, the order of \% mobility and bioavailability of the metals were: $\mathrm{Pb}>\mathrm{Cd}>\mathrm{Fe}>$ $\mathrm{Zn}>\mathrm{Cr}>\mathrm{Ni}>\mathrm{Cu}$. Results of geoaccumulation index $\left(\mathrm{I}_{\text {geo }}\right)$ indicated that the mine site soils were moderately to strongly polluted with $\mathrm{Cd} \mathrm{Cu}, \mathrm{Pb}$ and $\mathrm{Zn}$ while the control site was unpolluted with any of the metals. The results also indicated that the vegetables and indeed the ingestion route was the most significant contributor to non-carcinogenic risk followed by dermal contact and then inhalation. Total Hazard index (THI) for adult and children for all the studied metals were 1.68 and 4.50 respectively for Ishiagu-Enyigba site, 1.42 and 3.98 respectively for Elinwobvu-Enyigba site and 0.68 and 1.91 respectively for Ekawoke (control) site and these exceeded the safe level (>1). The total cancer risk were $1.51 \times 10^{-6}, 1.06 \times 10^{-6}$ and $2.14 \times 10^{-7}$ for Ishiagu-Enyigba, Elinwobvu-Enyigba and control site respectively and they all fall within and below the threshold safe range $\left(10^{-6}-10^{-4}\right)$ set by United States Environmental Protection Agency. These results strongly indicated non-carcinogenic risk of soil multiple heavy metals toxicity to humans especially in children. This calls for suitable policy for effective management of the environmental risk to ensure favourable public health.
\end{abstract}

Keywords: Mine site, Heavy metal pollution, Health risk, Bioavailability, Soils, Vegetables.

\section{Introduction}

Exploitation and mining of heavy metals contribute significantly to national income but adversely to environmental pollution [1]. In developing countries like Nigeria where artisan mining predominates, large quantities of tailings and waste water produced during the process are discharged into arable farmlands without regard to the environmental impact of such practice. Arable farmland soils contaminated with heavy metals can pose serious threat to the ecosystem and human health 
through different exposure routes. Heavy metals have been reported to cause varying degrees of toxicity in humans ranging from non-carcinogenic to carcinogenic risks $[1,2]$.

Heavy metals are non-biodegradable and as such persist in the environment. Depending on the physicochemical properties of the soil-plant root environment, heavy metals accumulate in edible portions of plants and may get ingested by humans that consume them [1]. Furthermore, heavy metals may be ingested directly from the soil when they get access to the body, it may be inhaled or taken up through dermal contact. The uptake of heavy metals by plants from soil depends largely on the different chemical forms/species of the metals in the soil and not the total heavy metals. Hence, plants uptake varies according to the chemical species which determines the mobility and bioavailability of the metals to the plants which also varies with plants species [3].

Overall, these heavy metals get into the body system where they impair normal metabolic and physiological processes in cells with varying clinical pathological manifestations. USEPA [4] health risk assessment model has been developed to assess the non-carcinogenic and carcinogenic risks associated with the levels of these metals contaminant. A good assessment will take cognizance of the various route of exposure.

The study area, Enyigba community in Abakaliki Local Government Area is one of the major mining communities in Abakaliki $\mathrm{Pb}-\mathrm{Zn}$ areas of Ebonyi state, Nigeria. The community has long exploration history and it is dominated by many illegal artisan mining activities. The inhabitants are predominantly farmers who use lands within the mining vicinity for cultivation of vegetables and other plant based food crops which they depend on for survival. The objectives of this study are to evaluate the different chemical forms of the heavy metals to ascertain their mobility and bioavailability, determine the level of the metals in the cultivated vegetables and assess the health risks of the heavy metals in the mine site soils and vegetables via ingestion, dermal contact and inhalation exposure routes. Data from this study will be invaluable in environmental policy for mining of heavy metals in the area.

\section{Material and Methods}

\subsection{Description of the Study Site}

The study area, Ishiagu-Enyigba and Elinwobvu-Enyigba in Enyigba Community, Abakaliki Local Government Area of Ebonyi State, Nigeria lies between latitude $6^{0} 11^{\prime} 30^{\prime} \mathrm{N}$ and longitude $8^{0} 8^{\prime} 115^{\prime \prime} \mathrm{E}$ with $21.8 \mathrm{~km}^{2}$ land area coverage. The topography of the area is gentle slope to plane with $59 \mathrm{~m}$ above the sea level. The flow direction of Ebonyi river tributaries is perpendicular to the mineralization areas. Geographically the area lies within the Benue trough (lower trough, southern part). It consists of creaticoius sediments of the ASU river group [1].

\subsection{Collection and Processing of Soil and Vegetable Samples}

Two farmlands within the vicinity of the mining site, Ishiagu-Enyigba (Southern) and Elinwobvu-Enyigba (Northern) and farm land within a site with no mining activity, Ekawoke (control site, about $3 \mathrm{~km}$ away from mining coverage) were mapped out for the study. At each location, the site was divided into ten transact sections and soils and vegetables (Telfairia occidentalis and Amaranthus hybridus) samples were collected and composited to obtain a representative sample using a coning and quartering method. At each collection point, the top soils were scrapped out, vegetable plants uprooted and put into a clean polythene bag. Then, the soils were collected up to $25 \mathrm{~cm}$ down using small plastic shovel into a clean polythene bag. The vegetable samples were properly washed with clean water to remove soil and other particles. Then they were oven-dried to constant weight. The soil samples were air-dried to remove any moisture present, large stones, organic particles and plant roots were removed from the soil and the soil was mechanically ground using clean mortar and pestle to obtain fine particles which was sieved with $<2 \mathrm{~mm}$ plastic mesh into a plastic container. The vegetable samples were ground crushed separately using a clean agate mortar and pestle to obtain smaller particles and then sieved with $<2 \mathrm{~mm}$ mesh to get powdered particles into a clean plastic container. These processed samples were stored and used for analysis.

\subsection{Heavy Metals Sequential Extraction Analysis in Soil and Determination in Plant Species}

The conventional method [5] outlined by Uba et al. [6] with modifications was employed for the sequential extraction of heavy metals. The heavy metals $(\mathrm{Cd}, \mathrm{Cu}, \mathrm{Cr}, \mathrm{Pb}, \mathrm{Fe}, \mathrm{Ni}$ and $\mathrm{Zn})$ in each fractions and in the digested processed plant samples [7] were analyzed using Atomic Absorption spectrophotometer (Varian spectra AA 55B Model). 


\subsection{Pollution Assessment Method}

The method of Geoaccumulation index ( $\left.\mathrm{I}_{\mathrm{geo}}\right)$ was used to assess the pollution level [3] using the computational equation described by Turekian and Wedepohl [8].

$$
\text { Geoaccummulation Index (Igeo) }=\log 2(\mathrm{Ci} / 1.5 \mathrm{Bi})
$$

Where $C_{i}$ is the measured concentration of the heavy metals in the environment, $B_{i}$ is the geochemical background value of the element [8] and the constant, 1.5 is used to minimize the variation of background values. The Igeo for each metal was calculated and classified as outlined by Ogunbanjo et al. [3]: unpolluted (Igeo $\leq 0$ ), unpolluted to moderately polluted $(0<$ Igeo $\leq 1)$, moderately polluted $(1<$ Igeo $\leq 2)$, moderately polluted to strongly polluted $(2<$ Igeo $\leq 3)$, strongly polluted $(3<$ Igeo $\leq 4)$, strongly to extremely polluted $(4<$ Igeo $\leq 5)$ and extremely polluted (Igeo $\geq 5$ ).

\subsection{Risk Assessment Method}

This study employed USEPA [4] to assess the human health risks associated with exposure to heavy metals in the study area via (i) direct ingestion of soil particles (ii) inhalation of soil particles (iii) dermal absorption of soil particles and (iv) diet of vegetables (T. occidentalis and A. hybridus) in adults and children. The intake defined as chronic daily intake dose (CDI in $\mathrm{mg} / \mathrm{kg} /$ day) of heavy metals during the exposure duration via the different exposure pathways is given in the equations in Table 1 [4] while the meaning and the value of exposure parameters is given in Table $2[2,7]$.

Table 1: Computational Equations for Chronic Daily Intake dose (CDI in $\mathrm{mg} / \mathrm{kg} /$ day) via different exposure routes.

\begin{tabular}{|c|c|c|c|}
\hline Exposure Pathway & & Exposure Calculations & \\
\hline Ingestion of Soil & $\mathrm{CDI}_{\text {ingestion-soil }}=$ & $\begin{array}{l}\text { CSxIRxCFxEFxED } \\
\text { BWxAT }\end{array}$ & (2) \\
\hline $\begin{array}{l}\text { Dermal Absorption } \\
\text { of Soil }\end{array}$ & $\mathrm{CDI}_{\text {dermal-soil }}$ & $\begin{array}{c}\text { CSxAFxSAxABSxCFxEFxED } \\
\text { BWxAT }\end{array}$ & (3) \\
\hline Inhalation of Soil & $\mathrm{CDI}_{\text {inhale-soil }}$ & 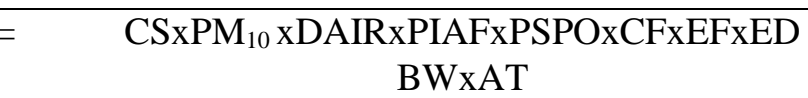 & (4) \\
\hline $\begin{array}{l}\text { Oral intake } \\
\text { vegetables }\end{array}$ & $\mathrm{CDI}_{\text {vegetables }}$ & $\begin{array}{c}\mathrm{C}_{\text {vegetable }} \times \mathrm{C}_{\text {factor }} \times \mathrm{D}_{\text {vegetable-intake }} \\
\mathrm{BW}\end{array}$ & (5) \\
\hline
\end{tabular}

Table 2: Meaning, value of parameters used in the assessment model and literature sources.

\begin{tabular}{|c|c|c|}
\hline Parameter & Meaning & $\begin{array}{c}\text { Value of } \\
\text { Parameters }\end{array}$ \\
\hline $\mathrm{CS}$ & Heavy metal content in soil $(\mathrm{mg} / \mathrm{kg})$ & Observed value \\
\hline IR & Soil ingestion rate (mg/day) & 100 \\
\hline $\mathrm{CF}$ & Conversion factor for soil $(\mathrm{mg} / \mathrm{kg})$ & $10^{-6}$ \\
\hline $\mathrm{EF}$ & Exposure frequency (day/a) & 350 \\
\hline ED & Exposure duration (a) & 30 \\
\hline BW & Body weight $(\mathrm{kg})$ & $\begin{array}{l}70 \text { (Adults) } \\
16 \text { (Children) }\end{array}$ \\
\hline AT & Average time (day) & $\begin{array}{l}365 \times E D \text { (non-carcinogens) } \\
365 \times 70 \text { (carcinogens) }\end{array}$ \\
\hline $\mathrm{PM}_{10}$ & $\begin{array}{l}\text { Content of inhale particulates in ambient air } \\
\left(\mathrm{mg} / \mathrm{m}^{3}\right)\end{array}$ & 0.15 \\
\hline DAIR & Daily air inhalation rate $\left(\mathrm{m}^{3} /\right.$ day $)$ & 14.5 \\
\hline PIAF & $\begin{array}{l}\text { Retention fraction of inhaled particulates in } \\
\text { body }\end{array}$ & 0.75 \\
\hline PSPO & Fraction of soil-borne particulates in air & 0.5 \\
\hline $\mathrm{AF}$ & Skin adherence factor $\left(\mathrm{mg} / \mathrm{cm}^{2}\right)$ & 0.2 \\
\hline
\end{tabular}




\begin{tabular}{|l|l|l|}
\hline SA & Exposed surface area of skin $\left(\mathrm{cm}^{2}\right)$ & 5408 \\
ABS & Dermal absorption factor & 0.001 \\
$\mathrm{C}_{\text {vegetable }}$ & Heavy metal content in vegetables $(\mathrm{mg} / \mathrm{kg})$ & Observed value \\
$\mathrm{C}_{\text {factor }}$ & Conversion factor for vegetables $(\mathrm{kg} . \mathrm{day} / \mathrm{mg})$ & 0.085 \\
\hline $\mathrm{D}_{\text {food-intake }}$ & Average daily intake of vegetables $(\mathrm{kg} / \mathrm{day})$ & 0.35 (Adults) \\
& & 0.22 (Children) \\
\hline
\end{tabular}

Human health risks of heavy metals via the different exposure route may lead to non-carcinogenic risks or carcinogenic risks [4] and can be computed using these equations:

$$
\begin{aligned}
& \text { Non-carcinogenic risk }=\mathrm{CDI} / \mathrm{RfD} \\
& \text { Carcinogenic risk }=\mathrm{CDI} \times \mathrm{SF}
\end{aligned}
$$

Where CDI is the chronic daily intake dose $(\mathrm{mg} / \mathrm{kg} /$ day) of heavy metals via different routes as evaluated, RfD is the oral reference dose $(\mathrm{mg} / \mathrm{kg} / \mathrm{day})$ of heavy metals and SF is the carcinogenic slope factor $(\mathrm{kg}$.day $/ \mathrm{mg})$. The value of the exposure parameters (RfD and $\mathrm{SF}$ ) via various routes $[2,7,9]$ is shown in Table 3.

Table 3: Values of exposure parameters (RfD and SF) of heavy metals used in the assessment model and literature sources.

\begin{tabular}{|l|l|l|l|l|}
\hline Metals & RfD ingestion $(\mathrm{mg} / \mathrm{kg} /$ day $)$ & $\begin{array}{l}\text { RfD dermal-contact } \\
(\mathrm{mg} / \mathrm{kg} / \text { day })\end{array}$ & $\begin{array}{l}\text { RfD } \\
(\mathrm{mg} / \mathrm{kg} / \mathrm{day})\end{array}$ & $\begin{array}{l}\mathrm{SF}_{\text {inhalation }} \\
(\mathrm{kg} . \text { day/mg })\end{array}$ \\
\hline $\mathrm{Cd}$ & $1.00 \times 10^{-3}$ & $1.00 \times 10^{-5}$ & $1.00 \times 10^{-3}$ & 6.10 \\
$\mathrm{Cr}$ & $3.00 \times 10^{-3}$ & $6.00 \times 10^{-5}$ & $2.86 \times 10^{-5}$ & 41.00 \\
$\mathrm{Ni}$ & $2.00 \times 10^{-2}$ & $5.40 \times 10^{-3}$ & $2.06 \times 10^{-2}$ & 0.84 \\
$\mathrm{Cu}$ & $4.00 \times 10^{-2}$ & $1.2 \times 10^{-2}$ & $4.02 \times 10^{-2}$ & \\
$\mathrm{~Pb}$ & $3.5 \times 10^{-3}$ & $5.25 \times 10^{-4}$ & $3.52 \times 10^{-3}$ & \\
$\mathrm{Fe}$ & $7.00 \times 10^{-1}$ & $7.38 \times 10^{-1}$ & $7.00 \times 10^{-1}$ & \\
$\mathrm{Zn}$ & $3.00 \times 10^{-1}$ & $6.00 \times 10^{-2}$ & $3.00 \times 10^{-1}$ & \\
\hline
\end{tabular}

\subsection{Statistical Analysis}

Results were expressed as mean \pm standard deviation of three replicates. Data obtained were analyzed using one way analysis of variance (ANOVA) with SPSS (version 15.0 Inc., USA) to compare heavy metal contents from the different sites. Figures followed by the same superscript alphabets along the same column are not statistically significant at $\mathrm{P}<0.05$ using Duncan Multiple Range Test (DMRT).

\section{Results}

The results of the chemical speciation of the heavy metals are shown in Table 4. The results showed that heavy metals were significantly higher $(\mathrm{P}<0.05)$ in the mining sites compared to the control site. The results also showed high $\%$ association of $\mathrm{Cd}, \mathrm{Pb}, \mathrm{Fe}$ and $\mathrm{Zn}$ in non-residual fraction and high \% association of $\mathrm{Cu}, \mathrm{Cr}$ and $\mathrm{Ni}$ in residual fraction, the order of \% mobility and bioavailability of the metals were: $\mathrm{Pb}>\mathrm{Cd}>\mathrm{Fe}>\mathrm{Zn}>\mathrm{Cr}>\mathrm{Ni}>\mathrm{Cu}$.

Table 5 showed the results of the level of heavy metal contents in the vegetables (T. occidentalis and A. hybridus). The results showed that the plants accumulated heavy metals in varying degrees and that the vegetable plants in mining site take up significantly $(\mathrm{P}<0.05)$ higher heavy metals when compared to that in the control site.

The geo-accumulation index values of the heavy metals in the soil of the study sites are shown in Table 6. These geoaccumulation index values showed that the mine site soils were moderately to strongly polluted with $\mathrm{Cd} \mathrm{Cu}, \mathrm{Pb}$ and $\mathrm{Zn}$ while the control site was unpolluted with any of the metals.

The results of the non-carcinogenic risk of heavy metals in the studied sites via different exposure routes are given in Table 7. The results showed that the vegetables and indeed the ingestion route was the most significant contributor to noncarcinogenic risk followed by dermal contact and then inhalation. The results indicated the the hazard quotient for the metals in all the sites studied were in the order: $\mathrm{Pb}>\mathrm{Cd}>\mathrm{Cr}>\mathrm{Cu}>\mathrm{Ni}>\mathrm{Fe}>\mathrm{Zn}$ and were always higher in children 
compared to adult. Total Hazard index (THI) for adult and children for all the studied metals were 1.68 and 4.50 respectively for Ishiagu-Enyigba site, 1.42 and 3.98 respectively for Elinwobvu-Enyigba site and 0.68 and 1.91 respectively for Ekawoke (control) site.

Table 8 showed the results of carcinogenic health risk of the metals for adults in the studied sites via inhalation exposure route. The results showed that the total cancer risk were $1.51 \times 10^{-6}, 1.06 \times 10^{-6}$ and $2.14 \mathrm{X} 10^{-7}$ for IshiaguEnyigba, Elinwobvu-Enyigba and control site respectively

\section{Discussion}

Mining has been reported as a serious anthropogenic source of heavy metals that contribute significantly to environmental pollution [1]. Results of this study (Table 4) are similar to earlier reports of higher heavy metals in mine site vicinity [10] as a result of metals fallout from the mining activities. Association of $\mathrm{Cd}, \mathrm{Pb}, \mathrm{Fe}$ and $\mathrm{Zn}$ with non-residual fraction is a reflection of their high mobility and hence bioavailability as similarly reported [3]. $\mathrm{Cu}, \mathrm{Cr}$ and $\mathrm{Ni}$ were highly associated in the residual fraction (Table 4) and may indicate the stability of the metals at the prevailing physicochemical properties of the soils [3].

The high level of heavy metals accumulated by the vegetable plants (Table 5) clearly agree with the fact that plants at contaminated sites develop mechanisms and take up higher quantities of the toxicant $[1,2]$. The differences in the metals taken by these plant species may be due the genetic differences in the plant species $[3,7]$

The high geo-accumulation values in farmland within the mine site vicinity showing moderate to strong pollution with $\mathrm{Cd}, \mathrm{Cu}, \mathrm{Pb}$ and $\mathrm{Zn}$ (Table 6) is comparable to earlier reports of anthropogenic pollution of mine site vicinity [3, 10]. The implication of this finding is a reflection of the health risk associated with uncontrolled mining activities [1, 10].

Non-carcinogenic health quotients for $\mathrm{Pb}$ and $\mathrm{Cd}$ were greater than the safe level (>1) (4) for children and total noncarcinogenic health risk for the metals were greater than the safe level (> 1) [4] for both adult and children in the studied sites (Table 7). This calls for concern as resident farmers within this mining vicinity are likely under threat of multiple heavy metal toxicity $[2,3,9,10]$.

Total cancer risk for adults in the studied sites (Table 8) fall below and within the safe level also called tolerable or acceptable carcinogenic risk $\left(10^{-4}-10^{-6}\right)$ as defined by USEPA [4]. Although the assessed cancer risk in the studied sites is at safe level, it should be noted that only inhalation route was assessed. Thus, there is no guarantee of cancer risks safety at the sites in future if all the routes is taken into cognizance and as such, resident farmers may still be under threat of cancer if appropriate precautionary measures are not in place. Implications of similar results have been reported $[3,9,10]$.

Table 4a: Heavy Metal Concentrations in each Fraction of the Soil Samples (mg/kg)/.

\begin{tabular}{|l|l|l|l|l|l|l|}
\hline \multirow{2}{*}{ SITES/FRACTIONS } & $\mathrm{Cd}$ & $\mathrm{Cu}$ & \multicolumn{2}{l|}{} \\
\cline { 2 - 7 } & $\mathrm{A}$ & $\mathrm{B}$ & $\mathrm{C}$ & $\mathrm{A}$ & $\mathrm{B}$ & $\mathrm{C}$ \\
\hline EXCHANGEABLE & $0.69 \pm 0.04$ & $0.63 \pm 0.03$ & $0.03 \pm 0.01$ & $1.98 \pm 0.07$ & $5.76 \pm 0.01$ & $0.84 \pm 0.02$ \\
\hline OXIDIZABLE & $0.36 \pm 0.01$ & $0.28 \pm 0.01$ & $0.01 \pm 0.01$ & $11.04 \pm 0.03$ & $11.88 \pm 0.02$ & $6.96 \pm 0.12$ \\
\hline ACID SOLUBLE & $0.42 \pm 0.03$ & $0.37 \pm 0.01$ & $0.02 \pm 0.01$ & $3.84 \pm 0.01$ & $6.30 \pm 0.01$ & $1.50 \pm 0.01$ \\
\hline REDUCIBLE & $0.58 \pm 0.07$ & $0.51 \pm 0.06$ & $0.03 \pm 0.02$ & $9.30 \pm 0.13$ & $5.64 \pm 0.03$ & $5.82 \pm 0.07$ \\
\hline RESIDUAL & $0.65 \pm 0.11$ & $0.52 \pm 0.05$ & $0.03 \pm 0.01$ & $45.36 \pm 0.06$ & $59.52 \pm 0.08$ & $35.58 \pm 0.03$ \\
\hline TOTAL METALS & $2.70^{\mathrm{c}}$ & $2.31^{\mathrm{b}}$ & $0.12^{\mathrm{a}}$ & $71.52^{\mathrm{b}}$ & $89.10^{\mathrm{c}}$ & $50.70^{\mathrm{a}}$ \\
\hline NON-RESIDUAL (\%) & 75.83 & 77.49 & 75.00 & 36.58 & 33.20 & 29.82 \\
\hline RESIDUAL (\%) & 24.07 & 22.51 & 25.00 & 63.42 & 66.80 & 70.18 \\
\hline MOBILE PHASE (\%) & 41.11 & 43.29 & 41.67 & 8.14 & 13.54 & 4.62 \\
\hline
\end{tabular}

\begin{tabular}{|l|l|l|l|l|l|l|}
\hline \multirow{2}{*}{ SITES/FRACTIONS } & $\mathrm{Cr}$ & $\mathrm{Pb}$ & \\
\cline { 2 - 7 } & $\mathrm{A}$ & $\mathrm{B}$ & $\mathrm{C}$ & $\mathrm{A}$ & $\mathrm{B}$ & $\mathrm{C}$ \\
\hline EXCHANGEABLE & $0.97 \pm 0.04$ & $0.86 \pm 0.01$ & $0.15 \pm 0.00$ & $20.32 \pm 0.04$ & $24.40 \pm 0.03$ & $8.65 \pm 0.02$ \\
\hline OXIDIZABLE & $0.28 \pm 0.01$ & $0.24 \pm 0.02$ & $0.04 \pm 0.01$ & $2.86 \pm 0.01$ & $1.90 \pm 0.01$ & $1.29 \pm 0.02$ \\
\hline ACID SOLUBLE & $0.82 \pm 0.03$ & $0.50 \pm 0.01$ & $0.09 \pm 0.02$ & $13.84 \pm 0.07$ & $15.02 \pm 0.05$ & $7.41 \pm 0.01$ \\
\hline REDUCIBLE & $0.21 \pm 0.01$ & $0.22 \pm 0.01$ & $0.02 \pm 0.01$ & $4.34 \pm 0.02$ & $2.74 \pm 0.01$ & $2.01 \pm 0.03$ \\
\hline RESIDUAL & $4.83 \pm 0.11$ & $3.14 \pm 0.03$ & $0.73 \pm 0.01$ & $17.72 \pm 0.02$ & $20.08 \pm 0.08$ & $10.04 \pm 0.02$ \\
\hline TOTAL METALS & $7.11^{\mathrm{c}}$ & $4.96^{\mathrm{b}}$ & $1.03^{\mathrm{a}}$ & $59.08^{\mathrm{b}}$ & $64.14^{\mathrm{c}}$ & $29.40^{\mathrm{a}}$ \\
\hline NON-RESIDUAL (\%) & 32.07 & 36.69 & 29.13 & 70.01 & 68.69 & 65.85 \\
\hline RESIDUAL (\%) & 67.93 & 63.31 & 70.87 & 29.99 & 31.31 & 34.15 \\
\hline MOBILE PHASE (\%) & 25.18 & 27.42 & 23.30 & 57.82 & 61.46 & 54.63 \\
\hline
\end{tabular}


Table 4b: Heavy Metal Concentrations in each Fraction of the Soil Samples (mg/kg) continued.

\begin{tabular}{|l|l|l|l|l|l|l|l|l|c|}
\hline \multirow{2}{*}{ SITES/FRACTIONS } & \multicolumn{3}{|c|}{$\mathrm{Fe}$} & \multicolumn{3}{c|}{$\mathrm{Ni}$} & \multicolumn{3}{c|}{$\mathrm{Zn}$} \\
\cline { 2 - 11 } & $\mathrm{A}$ & $\mathrm{B}$ & $\mathrm{C}$ & $\mathrm{A}$ & $\mathrm{B}$ & $\mathrm{C}$ & $\mathrm{A}$ & $\mathrm{B}$ & $\mathrm{C}$ \\
\hline EXCHANGEABLE & $950.40 \pm 1.23$ & $921.00 \pm 0.52$ & $409.20 \pm 1.71$ & $0.37 \pm 0.01$ & $0.13 \pm 0.01$ & $0.04 \pm 0.02$ & $43.18 \pm 0.05$ & $57.82 \pm 0.03$ & $5.48 \pm 0.55$ \\
\hline OXIDIZABLE & $271.80 \pm 1.06$ & $261.90 \pm 0.77$ & $292.80 \pm 0.85$ & $0.88 \pm 0.02$ & $0.72 \pm 0.03$ & $0.37 \pm 0.02$ & $79.04 \pm 0.13$ & $83.02 \pm 0.12$ & $12.80 \pm 0.18$ \\
\hline ACID SOLUBLE & $698.40 \pm 0.08$ & $595.20 \pm 1.14$ & $225.00 \pm 0.34$ & $0.76 \pm 0.02$ & $0.32 \pm 0.01$ & $0.08 \pm 0.00$ & $35.70 \pm 0.07$ & $42.04 \pm 0.15$ & $3.88 \pm 0.07$ \\
\hline REDUCIBLE & $955.20 \pm 1.15$ & $991.50 \pm 0.61$ & $402.00 \pm 1.16$ & $0.50 \pm 0.01$ & $0.39 \pm 0.03$ & $0.21 \pm 0.03$ & $42.86 \pm 0.04$ & $49.14 \pm 0.08$ & $6.24 \pm 0.03$ \\
\hline RESIDUAL & $972.30 \pm 0.85$ & $1173.60 \pm 1.03$ & $540.60 \pm 1.45$ & $5.47 \pm 0.07$ & $3.67 \pm 0.11$ & $1.34 \pm 0.01$ & $80.30 \pm 1.01$ & $75.42 \pm 1.01$ & $13.02 \pm 0.11$ \\
\hline TOTAL METALS & $3848.10^{\mathrm{b}}$ & $3943.20^{\mathrm{c}}$ & $1869.60^{\mathrm{a}}$ & $7.98^{\mathrm{c}}$ & $5.23^{\mathrm{b}}$ & $2.04^{\mathrm{a}}$ & $281.08^{\mathrm{b}}$ & $307.44^{\mathrm{c}}$ & $41.42^{\mathrm{a}}$ \\
\hline $\begin{array}{l}\text { NON-RESIDUAL } \\
(\%)\end{array}$ & 74.73 & 70.24 & 71.08 & 31.45 & 29.83 & 34.31 & 71.43 & 75.47 & 68.57 \\
\hline RESIDUAL (\%) & 25.27 & 29.76 & 28.92 & 68.55 & 70.17 & 65.69 & 28.57 & 24.53 & 31.43 \\
\hline $\begin{array}{l}\text { MOBILE PHASE } \\
(\%)\end{array}$ & 42.85 & 38.45 & 33.92 & 14.16 & 8.60 & 5.88 & 28.06 & 32.48 & 22.60 \\
\hline
\end{tabular}

Values are mean of three $(n=3)$ replicates \pm standard deviation

A = Ishiagu-Enyigba, $\mathrm{B}=$ Elinwobvu-Enyigba, $\mathrm{C}=$ Ekawoke (control) site

Figures followed by the same alphabets along the row are not significantly different at $\mathrm{P}<0.05$ using

Ducan Multiple Range Test (DMRT) for each metal at a site

Table 5: Levels of heavy metals (mg/kg dry weight) of Telfairia occidentalis and Amaranthus hybridus.

\begin{tabular}{|c|c|c|c|c|c|c|c|c|}
\hline \multirow{2}{*}{\multicolumn{2}{|c|}{ Samples }} & \multicolumn{7}{|c|}{ Metals (mg/kg dry weight) } \\
\hline & & Cd & $\mathbf{C u}$ & $\mathbf{C r}$ & $\mathbf{P b}$ & $\mathbf{F e}$ & $\mathbf{N i}$ & $\mathbf{Z n}$ \\
\hline \multirow[t]{3}{*}{ T. occidentalis } & A & $0.38^{\mathrm{c}} 0.01$ & $1.31^{\mathrm{b}} \pm 0.05$ & $1.05^{\mathrm{c}} \pm 0.02$ & $2.78^{\mathrm{b}} \pm 0.02$ & $3.95^{\mathrm{b}} \pm 0.03$ & $1.17^{\mathrm{c}} \pm 0.01$ & $4.86^{\mathrm{b}} \pm 0.03$ \\
\hline & $\mathrm{B}$ & $0.27^{\mathrm{b}} \pm 0.03$ & $1.68^{\mathrm{c}} \pm 0.01$ & $0.74^{\mathrm{b}} \pm 0.01$ & $2.84^{\mathrm{b}} \pm 0.07$ & $5.02^{\mathrm{c}} \pm 0.02$ & $1.03^{\mathrm{b}} \pm 0.02$ & $5.44^{\mathrm{c}} \pm 0.07$ \\
\hline & $\mathrm{C}$ & $0.11^{\mathrm{a}} \pm 0.01$ & $0.93 a \pm 0.02$ & $0.37^{\mathrm{a}} \pm 0.01$ & $1.33^{\mathrm{a}} \pm 0.03$ & $1.42^{\mathrm{a}} \pm 0.02$ & $0.63^{\mathrm{a}} \pm 0.01$ & $1.35^{\mathrm{a}} \pm 0.02$ \\
\hline \multirow[t]{3}{*}{ A. hybridus } & $\mathrm{A}$ & $0.72^{\mathrm{c}} \pm 0.02$ & $1.77^{\mathrm{b}} \pm 0.02$ & $1.59^{\mathrm{c}} \pm 0.02$ & $2.80^{\mathrm{b}} \pm 0.02$ & $4.18^{\mathrm{b}} \pm 0.11$ & $1.52^{\mathrm{c}} \pm 0.02$ & $4.04^{\mathrm{b}} \pm 0.02$ \\
\hline & $\mathrm{B}$ & $0.43^{\mathrm{b}} \pm 0.02$ & $2.26^{\mathrm{c}} \pm 0.03$ & $1.06^{\mathrm{b}} \pm 0.01$ & $2.91_{\mathrm{c}} \pm 0.03$ & $5.48^{\mathrm{c}} \pm 0.06$ & $1.13^{\mathrm{b}} \pm 0.02$ & $5.95^{\mathrm{c}} \pm 0.05$ \\
\hline & $\mathrm{C}$ & $0.19^{\mathrm{a}} \pm 0.01$ & $1.05^{\mathrm{a}} \pm 0.02$ & $0.67^{\mathrm{a}} \pm 0.01$ & $1.41^{\mathrm{a}} \pm 0.05$ & $1.50^{\mathrm{a}} \pm 0.02$ & $0.72^{\mathrm{a}} \pm 0.01$ & $1.44^{\mathrm{a}} \pm 0.02$ \\
\hline \multicolumn{2}{|c|}{ WHO/FAO (2007) guideline } & 0.20 & 73.30 & NA & 0.3 & 69.3 & 67.9 & 99.40 \\
\hline
\end{tabular}

Values are mean of three $(n=3)$ replicates \pm standard deviation .

A = Ishiagu-Enyigba, B = Elinwobvu-Enyigba, $\mathrm{C}=$ Ekawoke (control) site

Figures followed by the same alphabets along the column are not significantly different at $\mathrm{P}<0.05$ using

Ducan Multiple Range Test (DMRT) for each metal at a site.

Table 6: Geo-accumulation index values of metals in the soil of the study sites.

\begin{tabular}{|l|l|l|l|l|l|}
\hline Site & Element & $\begin{array}{l}\text { Average Shale } \\
\text { Values [8] }\end{array}$ & $\begin{array}{l}\text { Total Extractable } \\
\text { Metals } \mathbf{( m g / k g )}\end{array}$ & Igeo Value & Pollution Intensity \\
\hline $\mathrm{A}$ & $\mathrm{Cd}$ & 0.3 & 2.70 & 2.58 & Moderately to strongly polluted \\
& $\mathrm{Cu}$ & 45 & 71.52 & 0.08 & Unpolluted to moderately polluted \\
& $\mathrm{Cr}$ & 90 & 7.11 & -4.32 & Unpolluted \\
& $\mathrm{Pb}$ & 20 & 39.08 & 0.98 & Unpolluted to moderately polluted \\
& $\mathrm{Fe}$ & 47,200 & 7.848 .10 & -4.20 & Unpolluted \\
& $\mathrm{Ni}$ & 68 & 281.08 & -3.68 & Unpolluted \\
& $\mathrm{Zn}$ & 95 & 2.31 & 0.98 & Unpolluted to moderately polluted \\
\hline $\mathrm{B}$ & $\mathrm{Cd}$ & 0.3 & 89.10 & 2.36 & Moderately to strongly polluted \\
& $\mathrm{Cu}$ & 45 & 4.96 & 0.40 & Unpolluted to moderately polluted \\
& $\mathrm{Cr}$ & 90 & 64.14 & -4.64 & Unpolluted \\
& $\mathrm{Pb}$ & 20 & 3943.20 & 1.10 & Moderately polluted \\
& $\mathrm{Fe}$ & 47,200 & 5.23 & -4.17 & Unpolluted \\
& $\mathrm{Ni}$ & 68 & 307.44 & -4.28 & Unpolluted \\
& $\mathrm{Zn}$ & 95 & 0.12 & 1.11 & Moderately polluted \\
\hline $\mathrm{C}$ & $\mathrm{Cd}$ & 0.3 & 50.70 & -1.19 & Unpolluted \\
& $\mathrm{Cu}$ & 45 & 1.03 & -0.41 & Unpolluted \\
& $\mathrm{Cr}$ & 90 & 29.40 & -6.64 & Unpolluted \\
& $\mathrm{Pb}$ & 20 & 1869.60 & -0.03 & Unpolluted \\
& $\mathrm{Fe}$ & 47,200 & 2.04 & -0.52 & Unpolluted \\
& $\mathrm{Ni}$ & 68 & -5.64 & Unpolluted \\
& $\mathrm{Zn}$ & 95 & 41.42 & -1.78 & Unpolluted \\
\hline
\end{tabular}

ICSECT 135-6 
A = Ishiagu-Enyigba, B = Elinwobvu-Enyigba, C = Ekawoke (control) site

Table 7: Non-carcinogenic Health Risk/Hazard Quotient (HRI) of Metals via various Exposure Pathways.

\begin{tabular}{|c|c|c|c|c|c|c|c|c|c|}
\hline \multirow[t]{2}{*}{ Site } & \multirow[t]{2}{*}{ Pathway } & \multicolumn{2}{|c|}{ Cd } & \multicolumn{2}{|c|}{$\mathbf{C u}$} & \multicolumn{2}{|c|}{$\mathbf{C r}$} & \multicolumn{2}{|c|}{$\mathbf{P b}$} \\
\hline & & Adult & Child & Adult & Child & Adult & Child & Adult & Child \\
\hline \multirow[t]{6}{*}{ A } & Soiling & 0.00370 & 0.01620 & 0.00250 & 0.01070 & 0.00320 & 0.01420 & 0.02330 & 0.10200 \\
\hline & Soilderm-abs & 0.00400 & 0.01750 & 0.00009 & 0.00372 & 0.00175 & 0.00768 & 0.00167 & 0.00730 \\
\hline & Soilinh & 0.00003 & 0.00013 & 0.00000 & 0.00009 & 0.00278 & 0.01217 & 0.00019 & 0.00082 \\
\hline & T. occidentalis & 0.16150 & 0.44400 & 0.01393 & 0.03825 & 0.14867 & 0.41000 & 0.33714 & 0.92857 \\
\hline & A. hybridus & 0.30600 & 0.84200 & 0.01880 & 0.05175 & 0.22533 & 0.60667 & 0.34000 & 0.93429 \\
\hline & Total HRI & 0.47523 & 1.31983 & 0.03532 & 0.10450 & 0.38173 & 1.05072 & 0.70230 & 1.97297 \\
\hline \multirow[t]{6}{*}{ B } & Soiling & 0.00320 & 0.01380 & 0.00310 & 0.01340 & 0.00230 & 0.00990 & 0.02510 & 0.10970 \\
\hline & Soil Serm- & 0.00342 & 0.01500 & 0.00110 & 0.00482 & 0.00063 & 0.00537 & 0.00181 & 0.00792 \\
\hline & Soilinh & 0.00003 & 0.00011 & 0.00003 & 0.00011 & 0.00194 & 0.00846 & 0.00020 & 0.00089 \\
\hline & T. occidentalis & 0.11500 & 0.31600 & 0.01785 & 0.04900 & 0.10500 & 0.28833 & 0.34571 & 0.94857 \\
\hline & A. hybridus & 0.18300 & 0.50300 & 0.02403 & 0.06600 & 0.15033 & 0.41333 & 0.35429 & 0.97143 \\
\hline & Total HRI & 0.30465 & 0.84791 & 0.04610 & 0.13333 & 0.26020 & 0.72540 & 0.72711 & 2.03852 \\
\hline \multirow[t]{6}{*}{ C } & $\begin{array}{l}\text { Soiling } \\
\end{array}$ & 0.00020 & 0.00070 & 0.00170 & 0.00760 & 0.00050 & 0.00210 & 0.01150 & 0.05030 \\
\hline & Soilderm & 0.00018 & 0.00078 & 0.00006 & 0.00027 & 0.00026 & 0.00111 & 0.00083 & 0.00364 \\
\hline & Soilinh & 0.00000 & 0.00001 & 0.00001 & 0.00006 & 0.00040 & 0.00176 & 0.00009 & 0.00041 \\
\hline & T. occidentali & 0.04680 & 0.12900 & 0.00988 & 0.02725 & 0.05233 & 0.14400 & 0.16143 & 0.44286 \\
\hline & A. hybridus & 0.08080 & 0.22200 & 0.01115 & 0.03075 & 0.09500 & 0.26100 & 0.17114 & 0.47143 \\
\hline & Total HRI & 0.12798 & 0.35248 & 0.02280 & 0.06594 & 0.14849 & 0.40997 & 0.34500 & 0.96863 \\
\hline
\end{tabular}

\begin{tabular}{|c|c|c|c|c|c|c|c|}
\hline \multirow[t]{2}{*}{ Site } & \multirow[t]{2}{*}{ Pathway } & \multicolumn{2}{|c|}{$\mathbf{F e}$} & \multicolumn{2}{|c|}{$\mathrm{Ni}$} & \multicolumn{2}{|c|}{$\mathbf{Z n}$} \\
\hline & & Adult & Child & Adult & Child & Adult & Child \\
\hline \multirow[t]{6}{*}{$\mathbf{A}$} & Soiling & 0.00750 & 0.03300 & 0.00060 & 0.00240 & 0.00120 & 0.00560 \\
\hline & Soil derm-abs & 0.00008 & 0.00034 & 0.00002 & 0.00010 & 0.00007 & 0.00030 \\
\hline & Soilinh & 0.00006 & 0.00027 & 0.00000 & 0.00002 & 0.00001 & 0.00005 \\
\hline & T. occidentalis & 0.00240 & 0.00660 & 0.02485 & 0.06850 & 0.00690 & 0.01893 \\
\hline & A. hybridus & 0.00254 & 0.00699 & 0.03230 & 0.08900 & 0.00573 & 0.01573 \\
\hline & Total HRI & 0.01258 & 0.04719 & 0.05778 & 0.16002 & 0.01391 & 0.04062 \\
\hline \multirow[t]{6}{*}{ B } & Soiling & 0.00770 & 0.03370 & 0.00040 & 0.00160 & 0.00140 & 0.00610 \\
\hline & Soil derm-abs & 0.00008 & 0.00035 & 0.00001 & 0.00006 & 0.00008 & 0.00033 \\
\hline & Soilinh & 0.00006 & 0.00028 & 0.00000 & 0.00001 & 0.00001 & 0.00005 \\
\hline & T. occidentalis & 0.00304 & 0.00839 & 0.02190 & 0.06000 & 0.00770 & 0.02120 \\
\hline & A. hybridus & 0.00333 & 0.00916 & 0.02400 & 0.06600 & 0.00843 & 0.02317 \\
\hline & Total HRI & 0.01421 & 0.05187 & 0.04632 & 0.12768 & 0.01762 & 0.05085 \\
\hline \multirow[t]{6}{*}{ C } & Soiling & 0.00370 & 0.01600 & 0.00010 & 0.00060 & 0.00020 & 0.00080 \\
\hline & Soil derm-abs & 0.00004 & 0.00016 & 0.00001 & 0.00002 & 0.00001 & 0.00005 \\
\hline & Soilinh & 0.00003 & 0.00013 & 0.00000 & 0.00001 & 0.00000 & 0.00001 \\
\hline & T. occidentalis & 0.00086 & 0.00237 & 0.01340 & 0.03680 & 0.00191 & 0.00527 \\
\hline & A. hybridus & 0.00091 & 0.00250 & 0.01530 & 0.04210 & 0.00204 & 0.00560 \\
\hline & Total HRI & 0.00463 & 0.02117 & 0.02881 & 0.07953 & 0.00417 & 0.01172 \\
\hline
\end{tabular}

Table 8: Carcinogenic Health Risk of heavy metals for adults via inhalation Exposure Pathway.

\begin{tabular}{|l|l|l|l|}
\hline \multirow{2}{*}{ Metals } & \multicolumn{2}{c|}{ Sites } \\
\cline { 2 - 4 } & \multicolumn{1}{|c|}{$\mathbf{A}$} & \multicolumn{1}{c|}{$\mathbf{~ B}$} \\
\hline $\mathbf{C d}$ & $7.8867 \times 10^{-8}$ & $6.7472 \times 10^{-8}$ & $3.5051 \times 10^{-9}$ \\
\hline $\mathbf{C r}$ & $1.3958 \times 10^{-6}$ & $9.7379 \times 10^{-7}$ & $2.0222 \times 10^{-7}$ \\
\hline $\mathbf{N i}$ & $3.2098 \times 10^{-8}$ & $2.1036 \times 10^{-8}$ & $8.2054 \times 10^{-9}$ \\
\hline Total cancer risk & $1.51 \times 10^{-6}$ & $1.06 \times 10^{-6}$ & $2.14 \times 10^{-7}$ \\
\hline
\end{tabular}

Values are mean of three $(n=3)$ replicates \pm standard deviation

A = Ishiagu-Enyigba, B = Elinwobvu-Enyigba, $\mathrm{C}=$ Ekawoke (control) site

\section{Conclusion}

This study discovered high anthropogenic inputs of heavy metals $(\mathrm{Cd}, \mathrm{Cu}, \mathrm{Cr}, \mathrm{Pb}, \mathrm{Fe}, \mathrm{Ni}$, and $\mathrm{Zn})$ in the farmlands within the vicinity of the studied mining sites in Enyigba community, Abakaliki L.G.A., Ebonyi State, Nigeria. The study also revealed that cultivated edible vegetables (Telfairia occidentalis and Amaranthus hybridus) in farmlands within the 
mine sites vicinity accumulate heavy metals at quantities predisposing humans to non-carcinogenic toxicities. Overall, the results suggested that surrounding farmlands in the mine sites are highly polluted and could cause non-carcinogenic health risks leading to multiple heavy metals toxicities. Although, the assessment model was based on foreign data, vegetables and indeed the ingestion route was the most significant contributor to non-carcinogenic risk. Thus, efforts should be made to remediate the soils before planting edible plants. These findings will provide baseline data for policy makers and environmentalist in issuing and enforcing proper legislation in the management of mining sites for environmental and public health protection.

\section{Acknowledgements}

The authors are grateful to the Tertiary Education Trust Fund, Nigeria for the funding the conference participation and to the Rector, Akanu Ibiam Federal polytechnic Unwana, Ebonyi State, Nigeria, Ven. Dr. Ogbonnia Ibe-Enwo for approval for the use of his institution laboratories.

\section{References}

[1] N. A. Obasi, S. E. Obasi, S. O. Elom, K. M. Kalu, C. Aloke, I. O. Igwenyi, C. C. Isienyi and Justus Chinonso Attamah, "Health Risk Assessment of Heavy Metals in Ameri Lead-Zinc Mining Community via Consumption of Cassava (Manihot esculenta Cruz) in Ikwo L.G.A., Ebonyi State, Nigeria.” American-Eurasian J. Sustainable Agric., vol. 11, no.6, pp. 22-30, 2017.

[2] Y. Liang, X. Yi, Z. Dang, Q. Wang, H. Luo and J. Tang, "Heavy metals contamination and health risk assessment in the vicinity of a tailing pond in Guangdong, China," Int. J. Environ. Res. and Public Health, vol. 14, no. 1557, pp. 1-17, 2017.

[3] O. Ogunbanjo, O. Onawumi, M. Gbadamosi, A. Ogunlana and O. Anselem, "Chemical speciation of some heavy metals and human health risk assessment in soil around two municipal dumpsites in Sagamu, Ogun State, Nigeria," Chemical Speciation and Bioavailability, vol. 28, no. 1-4, pp. 142-151, 2016.

[4] United States Environmental Protection Agency (USEPA), "Risk assessment Guidance for superfund, Volume 1," Human Health evaluation Manual, Office of Emergency and Remedial Response, Washington, DC, USA, 1989.

[5] A. Tessier, P. G. C Campbell and M. Bissom, "Sequential extraction procedure for the speciation of particulate trace metals," Analytical Chemistry, vol. 51, no. 7, pp. 844-851, 1979.

[6] S. Uba, A. Uzairu, G. F. S. Harrison, M. L. Balarabe and O. J. Okunola, "Assessement of heavy metals bioavailability in dumpsites of Zaira metropolis, Nigeria," Afr. J. of Biotechnol., vol. 7, no. 2, pp. 122-130, 2008.

[7] A. Khan, S. Khan, M. A. Khan, Z. Qamar and M. Waqas, "The uptake and bioaccumulation of heavy metals by food plants, their effects on plants nutrients, and associated health risk: A review," Environ. Sci. pollut. Res. Int., vol. 22, pp. 13772-13799, 2015.

[8] K. K. Turekian and K. H. Wedepohl, "Distribution of elements in some major units of the earth's crust," Geol. Soc. Am. Bull., vol. 72, pp. 175-192, 1961.

[9] X. Zheng, W. Zhao, X. Yan, T. Shu, Q. Xiong and F. Chen, "Pollution Characteristics and Health Risk Assessment of Airborne Heavy Metals Collected from Beijing Bus Stations," Int. J. Environ. Res. Public Health, vol. 12, pp. 96589671, 2015.

[10] R. Xiao, S. Wang, R. Li, J. J. Wang, and Z. Zhang, "Soil heavy metal contamination and health risks associated with artesian gold mining in Tongguan, Shaanxi, China," Ecotoxicol. Environ. Saf., vol. 141, pp. 17-24, 2017. 